\title{
Children Literature: A Potent Tool in the Hands of Absentee Parent(s)
}

\author{
Iyabode Omolara Akewo Daniel \\ Department of English \\ School of Arts and Social Sciences \\ National Open University of Nigeria, \\ 14/16, Ahmadu Bello Way, Victoria Island \\ Lagos, Nigeria \\ E-mail: akewoauthe@gmail.com,idaniel@noun.edu.ng
}

Doi:10.7575/aiac.alls.v.6n.1p.150

URL: http://dx.doi.org/10.7575/aiac.alls.v.6n.1p.150
Received: 22/09/2014

Accepted: 05/12/2014

\begin{abstract}
Children literature remains the focus of discussions among those concerned with the positive socialisation of children within the African society. However, how it can serve for the socialisation of children by the home has not been clearly understood. This paper discusses the tangible role children literature can play in the socialisation process. It specifically focuses on the way the absentee parent(s) can effectively use children literature as a tool of child training. It outlined the nature of children literature as it exists in the Nigerian society. It identified some important techniques such as didactism, journey motif, child abuse, characterisation, etc. which writers use to convey their messages in Nigerian children literature. It identified how writers use aesthetics to attract, keep and teach children the needed morality in the society. It concludes by outlining the way that the teacher/parent can effectively bring to life children literature to youngsters and thus engage it for positive socialisation of children within the African social milieu.
\end{abstract}

Keywords: children literature, didactism, socialisation process, aesthetics, absentee parent(s)

\section{Introduction}

Children literature could be easily regarded as a recent phenomenon on the Nigerian literary scene at a time of her history. Nonetheless, this cannot be said to be strictly so anymore. This is because there is hardly any literary prize worth its salt nowadays in Nigeria that does not have a prize for children literature. It is thus obvious that the recognition of the importance of children literature is catching on across the nation and, most probably, across the African continent.

In as early as the 1960s, D. Olu Olagoke wrote in the preface of his plays, The Incorruptible Judge and The Iroko-man and the Wood-carver, that "Both boys and girls love good plays and interesting stories" (pages 3 and 5 respectively). He built this premise on the fact that the oral tradition of folk tales by moonlight told across the nation in the villages is normally loved by children. This fact is demonstrated practically by Bessie Head (1977) in her book The Collector of Treasures. Modise, the skilful story-teller ably sustained the interest of youngsters to an extent that they always wished for more. Many African writers have shown that this is a feature of the African culture that has been helpful in moulding the character of Africans into mobility before the intrusion of the modern Western culture that ruptured everything within the African life. But should Africans then remain at the same spot because their lives have been upturned by the Western culture? It would certainly be the height of foolishness.

To this writer, wisdom demands that the African makes use of what is Western in source to their advantage. How does this apply to the discussion at hand? Very simple. The African can adapt the Western to bow to the dictates of the culture it has come to colonise. In this wise, as Daniel (2010) argues, the coloniser can become the colonised through total domestication (cf. Kachru, 1995). Thus, the tales by moonlight can be reborn. How?

The days of tales by moonlight are almost not with us anymore (with the supersonic age of the television, home video drama and computer games). The best of the tales by moonlight that still exists in Nigeria is what the Nigeria Television Authority (NTA) is struggling to keep alive on the television. Digital television has penetrated even the most remote of homes on the African continent. Just possess your money to subscribe and you are digitally connected. The cell phone does not help matters as it is able to do so many things these days. Pinging is the in-thing for many Nigerian youngsters. It is thus obvious that a nation that does not key into the technological age will sink back into the dark ages. The fact is that whether we as a people like it or not, the younger generation is always ahead. One can thus relate to the President of Nigeria's (Goodluck Jonathan) initiative of catching them young by using their interest in modern technology (Facebook, specifically) as the avenue for giving to the younger generation tools of personal development. 
This clearly shows that it does not matter what we feel about the new social media, children would definitely hook up and connect anyway because, as all educators and parents know, children are always constantly faced with peer pressure. As such, what you fail to first tell your child, someone else will help you to tell them more than you think they should know; by then, you might have lost your privileged position in informing your child of what they need to know.

This thus makes it necessary to look at other means by which the positive effect of oral literature, as demonstrated in the African culture of tales by moonlight, is effectively used to teach moral mores of the African society and raise the noble men and women that the African continent deserves. Children literature, as demonstrated as a modern form, becomes the logical means of achieving the same purpose. The president's back to the books initiative is also a wise move.

\section{Objectives of the Study}

The focus of this study is to bring to the fore the help that children literature can offer to parents in training their children. However, more poignant is the way children literature can be of great use to parents that their career commitment do not allow them to give due attention to the socialisation of their children in order to develop in them the important values that make for responsible adults in the society. This is the focus of this study.

\section{Research Questions}

The questions we need to provide answers to include:

1. In what ways do children literature help in the socialisation of children?

2. What basic purpose does children literature serve in the socialisation process of children?

3. What are examples of literary works that can be used for children socialisation?

4. What sort of books can effectively serve as children literature?

5. What are the major techniques that are used by writers of children literature?

6. What are the ways that children literature can be used by parents to socialise their children?

These questions will guide our inquiry in this study.

\section{Who is an Absentee Parent?}

In this section, we discuss the concept of absentee parent. Psychology today describe parenting as "the most stressful and rewarding - job of your life." The implication is that parenting involves stress as well as joy. Parenting is seen in the sense of caring for out children. Absentee parenting could then suggest being absent from being able to do this duty of caring for our children. The question however is: who is saddled with the task of achieving this fit of socialising the children in the modern age through this modern means. Our view is that the parents and the teachers bear this responsibility. But much more is the responsibility of the parent as the actual custodian of children's developmental duties. We then wonder how a Lagos (Nigeria's old political capital but economic capital) parent is expected to achieve this feat as a dedicated career person. The concept of absentee parenting thus comes to the fore. The parent that leaves as early as $5 \mathrm{am}$ and comes back at $9 \mathrm{pm}$ in the name of career needs to have a means of dealing with the vacuum created (It is almost certain that this may more likely be the tale of most cities, but in different forms). The children literature could thus easily come in handy as a useful tool to be engaged in properly socialising children and developing good citizenry in the leaders of tomorrow. This paper thus presents the manner in which children literature can help parents to fill the socialisation gap, even while their career pursuit does not give them the chance to fill in this important gap that would create dysfunctional adults if children are not properly socialised.

\section{What is Children Literature?}

The logical and sensible question that comes to mind is: what does children literature entail?

Children literature could be defined as that written for children. This assumes of course that it is always in a written form. However, as noted above, this was not always so. It used to be oral in form. Nonetheless, it should be made clear that the concern in this paper is actually about literature that is in the written form. Another way of defining children literature is to say that it is literature written by children. This would seem to make a lot of sense when one perceives that children are singers and performers. Such people like Destiny Kids (Nigeria) and Michael Jackson (America) as a young boy and a host of others show that children could actually be artistes. It is however commoner to find adults as writers of children stories or stories that have relevance for children.

Other scholars have given their voice on the nature of children literature. Okafor (1992: 53), in attempting to define children literature, distinguished between children's books and children literature. She opines that "children's books are those published for children" while children's literature "is that published about children". This reveals a perceptive description of our earlier observation. Ikhigbonoareme (1992) sees children literature as "any books for children" ( $p$. 62). This reveals that the operational word for this definition is the qualifier 'children'. Ukala (1992:101), on the other hand, states that "Literature for children...includes such writings prepared especially for them [children] plus writings they have of their own" (quoting Huus, 1989: 30 [brackets added]).

The Library of Congress defines children literature (or children's literature, using its own term) as material written and produced for the information and entertainment of children. One would have been tempted to see this definition as going beyond the written but also involving other media too. However, the word written as stated in this definition actually shows that the library views children literature essentially as that which is written. This position seems to fit what we have in mind here. Encyclopaedia Britannica sees it as the body of written works and illustrations that are 
meant to entertain children. The key focus here is that the literature is for children but usually prepared for them by adults.

It is obvious from these definitions that children literature may be regarded as those stories, plays, and poems published for and about children. Moreover, it could also be called those they have chosen to read and enjoy on their own even if it had not been specifically directed at them or written about them. However, one important omission is noticed in all these definitions. This is why the term 'published' has been carefully selected in our summary of the definitions.

The question to ask ourselves is: do children not write creatively too? What category should we place this? It is clear that one of the important things that writing for children should achieve, beyond the commonly held view, is that it should foster in the child the ability to create their own story.

\section{History of Children Literature in Nigeria}

As has been noted above, children literature is actually not a recent phenomenon. But written children literature is relatively a recent phenomenon within the Nigerian socio-cultural context. Nonetheless, as it would be observed, it might not have been as early as the time that the likes of Oliver Twist by Thomas Hardy or that of the period of Cinderella, it is still early enough to grow with the period of Nigerian enlightenment. It has thus been suggested that the 1960s mark the beginning of children literature publishing in Nigeria. Segun (1992) notes that spirited attempts were made by some Africans to counter the negative contents of the European books that children had to read in the earlier part of the 20th century. Such early attempts include Azudu by William Balkie, Omenuko by Peter Nwana, Rowan Bogaja Kwamin Sani Lukum (1955) co-authored by Abubakar Imam and D. O. Fagunwa's Ogboju Ode ninu Igbo Olodumare. The question to be asked then is that: why do people write children literature?

\section{Purpose of Children Literature}

Like its precursor, children tales by moonlight, children literature is believed to be written essentially to teach children morals, social ethics and proper conduct. It is also believed to be for educating children on what social expectation of them is. It is thus seen as an important socialisation instrument. In this age and period that so many children are expected to have been exposed to one level of education or the other, it is assumed that many of the children could read. Nonetheless, one expects that children whose parents may really not have the time to give them attention and personal education are usually those of educated parents that most often than not have to pursue one career or the other, which most often means they are working for someone.

It should be noted that there is hardly any book one would read that will not have one moral or the other to teach. Even the so-called slap-stick comedies do teach morals. But in African children literature, there seems to be such care to teach children one moral or another. Didactism thus seems the major guiding philosophy for the average writer of children fiction. They probably see it in the manner of having a duty to the society to teach the children just like a teacher. In the manner of the old village story teller (cf. Head, 1977), they probably feel it is crucial to pass on the important lesson of good always triumphing over evil to the children. Through these creative works, children are given the consciousness of their civic responsibilities and duties. They learn about obedience to constituted authority. They learn about the culture of their people as well as their society's world view. The major focus then seems to be didactism more than entertainment. We could call this 'didactic entertainment', if there exists such a thing.

How does this relate to the discussion here? Didactically focused literature becomes a means of socialisation and education. It can thus be seen as a tool that can truly help the absentee parent in child training to achieve positive socialisation.

\section{Some Examples of Literary Works that Teach Children Morals}

The following texts are briefly discussed to exemplify the concept of didactism as a means of socialisation.

\subsection{The Incorruptible Judge}

This is one of the classics of the Nigerian children literature. It was published by Olu Adegoke. The major focus of this dramatic text is that it teaches the child to expose corruption and not to cover or partake in it. Also, the common concept of good always triumphing over evil is played out at the end. It is also possible to use this book to teach children that being in a position of responsibility demands being responsible, otherwise one may lose it in a disgraceful manner as it happened to Agbalowomeri.

\subsection{The Iroko-Man and the Wood-Carver}

This play teaches that patriotism has its reward. It condemns greed. It teaches that being hard working and dedicated eventually pays off even though it may take a bit of time to get the deserved recognition. Also it teaches that good supersedes the power of evil as seen in the harm that could not attend Agbegi after he cut down the tree despite the Iroko-Man's threat.

\subsection{Sugar Girl}

This novella tells the story of a young girl with a sweet nature despite the vicissitudes of life. Ralia has a tough childhood as a young girl but she is not bitter about this. The story teaches of her obedience to her parents despite their indigent and disabled states. Her adventure in the story started with the desire to help a little bird. It also teaches about the kindness of the hunter to Ralia. The responsible Prince also took care of her when he accidentally hurt her. At the end, Ralia is not lost because she is not a bad girl and that she is needed by her parents, the writer appears to be teaching with the story. 


\subsection{Without a Silver Spoon}

In Eddie Iroh's short novel, we learnt that poverty is no excuse to become a thief. It is even revealed in the text that an over-indulged child may suffer moral bankruptcy. In the end, Ure Chokwe is justified and vindicated because he remained faithful despite being falsely accused. Moreover, another important lesson the story teaches is that one should never be hasty in judgement as one may actually be proved wrong at the last as it happened in the case of Teacher Steve's accusation of stealing levelled against Ure and that of the school against the same boy. They all had to apologise to Ure when the truth was finally revealed. This could have been avoided.

\subsection{Hero Number One}

This novel also teaches some important lessons. It is obvious that having a village background does not make one totally blank, or what would normally be called a tabular rasa. Adindu also had things to teach his city cousin too, even though he learnt a lot about city life from the cousin. Moreover, the book teaches of good neighbourliness and the importance of both parents to the child. But one wonders at the kind of lesson the book is trying to teach by making Adindu to disobey his father in going to the city. Considering how impressionable that the young age, which is the focus of the book, the author could have allowed Adindu to have his adventure without having to become a disobedient child. Nonetheless, one must say that the Nigerian family set up may mean that the book would never be written in that only few dads would give such liberty to their children. However, one may say, as it turned out for good for Adindu, maybe it is: there is a good kind of disobedience. But the question here is: how does a young child determine what is good and what is bad?

\subsection{Stories My Mother Told Me}

In this book, children have a lot to learn from the fables and folk tales. It is observed that mainly the same thematic focus, good behaviour is better and more acceptable than evil acts, predominates throughout the different stories.

\subsection{Children's Rhymes}

The Mamman Vasta's Children's Rhymes contains a lot of advice for the young. Examples of these include:
a. The opening poem, "Beginning and Ending" which teaches persistence,
b. "Keep the Garden Clean" which teaches cleanliness in order to stay healthy,
c. "Do not Giggle" which advises the young to listen to advice from the elders;
d. "Someone to Play with", which teaches children spirituality.

These and many other poems in the collection teach children real life lessons.

\section{Children and Aesthetics}

Smith (1953:21) asserts that “... poems are for pleasure: understanding will grow with the reader.” Our opinion is that children should be able to have a good laugh and be tickled when reading a story, poem or play. Enjoyment should be of prime importance even when giving morals. Smith quoted above seems to feel that aesthetics is of prime importance in gaining the children's interest in order to impart whatever values we want to; this we believe to be so too.

Supporting this view, Ashimole (1992:72) states that "Aesthetics ... plays a lot of significant role in children's literature as it involved attracting and holding the attention of the child." Thus, we find Vatsa's poems to be the most attractively illustrated of the available texts. Moreover, the print is bold, adding to the beauty of the work. We are of the opinion that children literature need to reflect the time of life it is meant for: childhood. We should never forget that beauty is an important feature of childhood and the things children find captivating are new and/or beautiful things. This appears to make a lot of sense when one considers the fact that children will give no peace to their parent(s) when a communal festival is approaching until they (parent) provide a new set of clothing items; it does not matter most often if the parent(s) have to even borrow to provide these things. The important thing is that the items are available for use at the occasion.

\section{0 .Techniques Involved in Children Literature}

The commonest technique employed by the Nigerian writers of children literature appears to be that of a journey motif in which the child protagonist will make a journey from one point to another. This journey could be physical, psychological or social. The children protagonists in these stories usually have one deficiency or the other which make them seek to better themselves by moving from their locales. In short, to develop, they need to move from one point of being or location to the other. We see such movements being the common focus of stories like Chike and the River, Ure in Without a Silver Spoon that had to live with his teacher to get education. In Hero Number One, Adindu went to live with his Uncle in the city to get education and become religiously 'modern'!

The movement of Ajala Oni is actually both physical and psychological. On his movement from place to, he encountered Agbalowomeri (whose name actually means: One that takes from those that do not have); this led to his psychological liberation of discovering his patriotic tendencies. In Sugar Girl, Ralia's journey led her into the social mobility of befriending a prince. The journey motif is a common technique in Nigerian children literature. 
Another important method is the ideology of good and truth always triumphing over evil in the end. The law of karma is very effective here. This can be seen as an attempt to show children a constant moral: that it is better to be good and straight-forward in all their dealings. This is played out in Ajala Oni docking Agbalowomeri despite Ajala's apparent helplessness compared to the larger than life image of Agbalowomeri. Ayawa's innocence is finally revealed by Ralia's timely return. In Without a Silver Spoon, Erugo, the spoilt boy that implicated Ure, is finally found out. The short stories present many such incidents too. One of such is the wicked brother that killed his younger brother is eventually exposed by the dead brother's bone that sings.

Another effective technique is characterisation. Through characterisation, the writers try to get across to the readers. This is an effective and important technique in that it holds up examples of other children or characters to the children, showing how these respond to different situations. In Sugar Girl, Ralia is characterised as a child that is not disobedient despite her lot in life - an only child, blind mother, injured father and an impoverished home. She is instead shown as an obedient and respectful girl. This makes all that come across her way love her and always ready to help her.

Ure Chikwe is both dutiful and honest. These same characteristics led to his eventual vindication. Despite coming from a poor background, he does not take what is not given to him to satisfy his hunger when his master is not around. Neither does he envy his mates because they are better off financially. Moreover, he does not despise his parents for their poverty. Instead, he is sympathetic and ready to help out. Ajala Oni is another positive character that decides to follow truth courageously rather than keep quiet when he has the opportunity of exposing Agbalowomeri. He could have quietly gone home without doing anything. The judge is also another positive character in the play that holds up an example of honesty and career interest to the young. The attempt to bribe him did not take him off the course of justice.

The abused child motif is also an important technique exploited widely by the Nigerian children literature writers. Here, a child is made to undergo sufferings and agonies due to loss of a parent(s) or parent(s) that is poor or irresponsible. This generally leads to the child having to live with someone that is expected to be able to provide the necessities of life for the child. But what usually gets meted out to such children is maltreatment and unkindness. Such children are treated worse than slaves. However, eventually, the children get a break in the form of an unexpected opportunity in life and succeed through providential provision of education through scholarship as is the case of Adah in Buchi Emecheta's Second Class Citizen, A Lucky Chance and Born to Win are other examples.

\section{Children Literature and the Way Forward}

It has been generally observed that stories are written for boys and girls to read, to learn morals and develop their minds. Ikhigbonoareme (1992: 62-3) states that some of the reasons writers write for children are "to foster reading habits in them, to provide pleasure, entertainment and enhance their educational development." This seems a laudable goal but, is it what obtains presently?

As previously noted, the perceived concentration of most Nigerian writers seems to be mainly to impart one moral or the other. This is an important aspect of what children should seek to achieve, especially if it is to be useful to the parents for pedagogical and character formation purposes. We are, however, of the opinion that it is also important to train children in the habit of reading privately for pleasure. The present tendency of most parents buying only books recommended for children in the school curriculum is not good enough. We need governmental, non-governmental groups and individuals to provide libraries where children can access books for their reading pleasure. The librarians in charge should be professionals or trained amateurs in case of school or balloon library. But all these personnel must have specialised interest in children to provide good advice to the young ones in order to inculcate in them the good taste for good books.

Critics have commented on the issue of the dearth of writers or writings in children literature, especially poetry and drama (cf. Ukala, 1992:102). There seems to be one important thing being overlooked: the need to develop the creative ability in the children themselves. Prize can be given for the writing of good poems, stories and dramatic pieces. A wellorganised school magazine is a good avenue. Also, in the course of teaching a literary text, students can be encouraged to write their responses to a particular idea in the text. They may also develop a story of their own out of the text or write about similar experiences. This would then be put together as a class work, which may be published, if the teacher can make the effort to pursue it to that point, if the stories are good enough (cf. Twist, 1989:27-30 \& Bench, 1989: 3140).

The dearth of children's poems and drama is another important issue that we need to tackle. In encouraging creativity in children, poems and plays should be given special place. Young students and those of the higher institutions should be encouraged to write poems and dramatic pieces expressing realistic themes of interest to children. These could be duly rewarded and /or published. In such a manner, the creative form can grow with the writers as our base of writers for children.

Another important thing that can help move children literature forward is the presentation of realistic themes. We should move away from the romantic to the realistic. We need to write about science, about television, about technology, about mothers that are career women and players in the social arena, about mothers and fathers that cooperate to provide for the family, about bad children and why they are bad, and about good children and what helped them to be good. For God's sake, children are no angels; and that is the truth! 
In order to catch and hold the interest of our children, we need well-illustrated books and captivating titles. The cover of the book in combination with interesting themes will surely help wean our children from the drug called the television. We must, however, comment that the parents need to help their children by enforcing rules of particular reading hours.

\section{How Do we Teach Children Literature?}

Whether you are a classroom teacher or an interested parent, this section will greatly help you to achieve your intended target for the children under your educational care. Under this section, some general tips that can help in presenting children literature in the class in a manner that will gear up the children's interest in reading literary texts is provided. Thus the parent (also referring to the teacher) should encourage the children to read the text on their own. They may note down the general idea they got from their reading. All these different ideas they discover are then discussed, either in the class or at home with their parent(s). This should then make them to re-read the text, realising that there are many possible ways to reading the text. The parent (teacher) may encourage them to draw the picture depicting their understanding of what they find most striking in the text. They should be made to know that their artistic ability is not what is needed but their vision of what they read. This is to avoid their giving it out to someone else to draw.

From this point, the diction of the text may be investigated to discover the prevalent concept. This will be revealed by the commonest kinds of vocabulary used. Their synonyms and antonyms may be written out in binary relations. At this point, the parent (teacher) may explain the words the children may still find difficult to understand.

Literature should be able to tickle the imagination and raise questions in the minds of the readers. Children literature should do no less. The parent (or the teacher, as the case may be) should encourage a questioning attitude in the children and lead them to discover the answers by themselves. This will be a better approach than the present practice by many Nigerian students of depending absolutely on the 'almighty and all-knowing' teacher. This leads to intellectual laziness on the students' part. This laziness usually makes the work of a higher institution professor who tries to wake up this questioning attitude in them an uphill task. The children need to learn that it is not everything they read or hear that should be taken hook, line and sinker. This can only happen if their critical reading sense has been awakened either by their parents or their teacher.

Another helpful way is through the effective use of the balloon library in the class. This technique is actually relevant essentially in the class. The discussion will thus be more class-focused here. Children are encouraged to buy different texts, which are then pulled together. The pupils are then encouraged to borrow from this library and return same within two days. Everybody must read through all the books in the library for the term. The teacher(s) can check up the librarian's record of borrowers and from time to time ask any member of the class to discuss any book the record shows the person has borrowed. At the end of the term, time for general discussion could begin.

Prizes may be awarded to the fastest reader, neatest handlers of the library's books, etc. At the end of the term, a class magazine may be produced of the different creative or scholastic writings that may grow out of their readings. Some parts of these productions may also be made part of their continuous assessment if the teacher so wishes.

Importantly, in choosing any teaching method, the students' age range should be of utmost importance. This is also the case in selecting reading materials, for the children. However, it must be stressed that class activities must centre on the students, no matter what one chooses to teach in the literature lessons. The teacher should always be a mere moderator.

A good parent that really wants to be effective may thus learn to adopt these methods and apply them in the home, where possible. The absentee parent may thus be able to be there for their children and be fully involved in their education just by engaging children literature as an ally in training their children. It is thus obvious that the careerfocused parent can still very much be able to socialise their children well through involving children books to help them in their child training process.

\section{Conclusion}

We have tried to trace the genesis of the children literature. We have also discussed some major philosophical guiding principles discovered in presenting these ideological focuses. We then finally suggested ways and manner in which children literature can become a more effective arm of our educational and socialisation agent of development for the children. It appears it is only when we allow our children to be children and we moderators of their growth can we have children literature becoming effective in its relevance to our children.

\section{References}

Achebe, C. (1996). Chike and the river. Cambridge: Cambridge University Press.

Adedeji, R. (1978). Stories my mother told me. Ibadan: HEB (Nig.) Plc.

Ashimole, E. O. (1992). Nigeria children's literature and the challenges of social change. In C. Ikonne, E. Oko, \& P. Onwudinjo (Eds.) Children and literature in Africa, (pp. 70-81). Ibadan: HEB.

Bench, P. (1989). Teasing our 'the tiger': Exploring teaching strategies with second-years. In M. Burton Enjoying texts, (pp. 31-40). Leckhampton: Stanley Thornes (Pub.) Ltd.

Daniel, I. O. (2010). Transliteration as communication weapon in Nigerian English. A paper presented at the 27th Annual Conference of the Nigerian English Studies Association (NESA) at the Covenant University, Ota, Ogun State between 2 and 5 November, 2010. 
Daniel, I. O. A. (2014). Linguicide and Nigerian languages: Green economy as a strategic

platform for preservation. Accepted in Govinda Bhandari (Ed.) Green Economy (A book project by Research and

Training Environment Professionals' Training and Research Institute (EPTRI) Kathmandu, Nepal).

Eboh, E. I. (1987). Hero number one. Ibadan: University Press Plc.

Emecheta, B. (1974). Second class citizen. Glasgow: Fontana/Collins.

Encyclopaedia Britannica (2013). Children's literature. Retrieved September 13, 2013 from

http://www.britannica.com/EBchecked/topic/111289/childrens-literature

Head, B. (1977). The collector of treasures and other Botswana village tales. London: Heinemann.

Ikhigbonareme, E. B. (1992). Writing and publishing children's literature: Problems and prospects. In C. Ikonne, E. Oko, \& P. Onwudinjo (Eds.) Children and literature in Africa, (pp. 61-69). Ibadan: HEB.

Iroh, E. (1981). Without a silver spoon. Ibadan: Spectrum books Ltd.

Kachru, B. (1995). Foreword. In A. Bamgbose, A. Banjo \& A. Thomas (Eds.) New Englishes: A West African perspective, (pp. iii-viii). Ibadan: Mosuro Publishers and Booksellers.

Library of Congress. (2013). Children literature. Retrieved September 13, 2013 from

http://www.loc.gov/acq/devpol/chi.pdf

Nwakoby, M. (1980). A lucky chance. Ibadan: Macmillan (Nig.) Publishing Ltd.

Ogu, C. J. (1985). Born to win. Ibadan: Macmillan (Nig.) Publishing Ltd.

Okafor, N. R. (1992). Technical and economic problems of writing and publishing children literature in Africa with particular reference to Nigeria. In C. Ikonne, E. Oko, \& P. Onwudinjo (Eds.) Children and literature in Africa, (pp. 5260). Ibadan: HEB.

Olagoke, D. O. (1962). The incorruptible judge. Ibadan: Evans Brothers (Nig.) Publishing Ltd.

Olagoke, D. O. (1962). The iroko-man and the wood-carver. Ibadan: Evans Brothers (Nig.) Publishing Ltd.

Onadipe, K. (1964). Sugar girl. Ibadan: African Universities Publishers.

Psychology Today. (2014). All about Parenting. Retrieved 17 July, 2014 from http://www.psychologytoday.com

Segun, M. D. (1992). Children's literature in Africa: Problems and prospects. In C. Ikonne, E. Oko, \& P. Onwudinjo (Eds.) Children and literature in Africa, (pp. 24-42). Ibadan: HEB.

Smith, J. A. (1953). Children's verse. London: Faber and Faber Ltd.

Twist, C. (1989). 'Through a fine web': A post-structural approach to working on a text with younger pupils. In M. Burton Enjoying texts, (pp. 27-30). Leckhampton: Stanley Thornes (Pub.) Ltd.

Ukala, S. (1992). Fading away as morning stars? A review of the interest of Nigerian children in literary drama. In C. Ikonne, E. Oko, \& P. Onwudinjo (Eds.) Children and literature in Africa, (pp. 79-106). Ibadan: HEB.

Vatsa, M. J. (1980). Children's rhymes. Enugu: Fourth Dimension Publishing Company Ltd. 